\title{
Business-to-Business Buying: Challenges and Opportunities
}

\author{
Rajdeep Grewal • Gary L. Lilien • Sundar Bharadwaj • Pranav Jindal • \\ Ujwal Kayande • Robert F. Lusch • Murali Mantrala • Robert W. Palmatier • \\ Aric Rindfleisch • Lisa K. Scheer • Robert Spekman • Shrihari Sridhar
}

Published online: 7 March 2015

(C) Springer Science+Business Media New York 2015

\begin{abstract}
In this article, we lay out the challenges and research opportunities associated with business-to-business (B2B) buying. These challenges and opportunities reflect four aspects of B2B buying that the Institute for the Study of Business Markets (ISBM: www.isbm.org) has identified through a Delphi-like process: (1) the changing landscape of B2B buying, (2) the increasing sophistication of sellers, (3) the impact of technological changes, and (4) the increasing importance and growth of emerging markets. For each of these four areas, we identify the relevant background, key issues, and pertinent research agendas.
\end{abstract}

Keywords B2B buying - Sophistication of sellers .

Technological changes $\cdot$ Emerging markets

\section{Introduction: Emerging Challenges for B2B Buying}

According to the most recently published U.S. Department of Commerce (2010; http://www.census.gov/econ/estats/2010,

R. Grewal $(\bowtie) \cdot$ P. Jindal

Kenan-Flagler Business School, University of North Carolina,

Chapel Hill, NC, USA

e-mail: grewalr@unc.edu

G. L. Lilien · S. Sridhar

Smeal College of Business, Pennsylvania State University,

University Park, PA, USA

S. Bharadwaj

Terry College of Business, University of Georgia, Athens, GA, USA

U. Kayande

Melbourne Business School, University of Melbourne,

Melbourne, Australia

R. F. Lusch

Eller College of Management, University of Arizona, Tucson, AZ, USA assessed January 2015) statistics, business-to-business (B2B) transactions account for $\$ 10.7$ trillion, or nearly $42 \%$, of total U.S. revenues. Because the United States accounts for roughly $22 \%$ of the global economy (http://en.wikipedia.org/wiki/ World_Development_Indicators, 1 July 2014), global B2B buying reasonably is expected to approach $\$ 50$ trillion in transactions (i.e., $\$ 10.7$ trillion/.22). Understanding these transactions - including the forces that drive them and how changes in the environment affect them - is essential to the organizations that participate in this enormous global marketplace.

In addition, B2B buying behaviors differ substantially from consumer buying behaviors, in several ways. First, B2B buying entails satisfying derived demand. Organizations purchase products to meet the needs of their buyers. Impulse-buying is rare; clearly stated, objective criteria, such as meeting production needs and schedules at a minimum cost, usually drive the choice process. Second, because more than one person is involved in the purchase decision process, purchasing managers rarely make a buying decision independent of the influence of

M. Mantrala $\cdot$ L. K. Scheer

Robert J. Trulaske, Sr. College of Business, University of Missouri, Columbia, MO, USA

R. W. Palmatier

Foster School of Business, University of Washington, Seattle, WA, USA

A. Rindfleisch

College of Business, University of Illinois at Urbana-Champaign, Champaign, IL, USA

R. Spekman

Darden School of Business, University of Virginia, Virginia, VA, USA 
Table 1 Evolution of B2B buying research (Source: [31], p. 373)

\begin{tabular}{|c|c|c|c|c|c|}
\hline $\begin{array}{l}\text { Relationship } \\
\text { and } \\
\text { network } \\
\text { models }\end{array}$ & & $\begin{array}{l}\text { Relationships } \\
\text { dyadic } \\
\text { marketing } \\
\text { concept } \\
\text { Bonoma and } \\
\text { Johnston [8] }\end{array}$ & $\begin{array}{l}\text { Relationship models and network } \\
\text { Hutt and Reingen [23] } \\
\text { Turnbull and Valla [63] }\end{array}$ & $\begin{array}{l}\text { Integrative relationship } \\
\text { models Cannon and } \\
\text { Perreault [10] Iacobucci } \\
\text { and Ostrom [24] }\end{array}$ & $\begin{array}{l}\text { Network models with } \\
\text { incomplete data, } \\
\text { multiplexity, dynamics } \\
\text { Van den Bulte and } \\
\text { Wuyts [66] }\end{array}$ \\
\hline $\begin{array}{c}\text { Bargaining } \\
\text { models }\end{array}$ & $\begin{array}{l}\text { Economicl } \\
\text { equilibrium } \\
\text { models-two } \\
\text { party/single issue } \\
\text { Nash [38] }\end{array}$ & $\begin{array}{l}\text { Multi-issuel } \\
\text { multi-agent } \\
\text { models } \\
\text { Keeney and } \\
\text { Raiffa [29] }\end{array}$ & $\begin{array}{l}\text { Behavioral economic models } \\
\text { Raiffa [43], Neslin and } \\
\text { Greenhalgh [39] }\end{array}$ & $\begin{array}{l}\text { Process models of } \\
\text { negotiations } \\
\text { Balakrishnan and } \\
\text { Eliashberg [6] }\end{array}$ & $\begin{array}{l}\text { Agenda strategies with } \\
\text { buying teams Patton and } \\
\text { Balakrishnan [41] }\end{array}$ \\
\hline $\begin{array}{l}\text { System and } \\
\text { group } \\
\text { choice } \\
\text { models }\end{array}$ & $\begin{array}{l}\text { Arrow's } \\
\text { impossibility } \\
\text { theorem Arrow } \\
\text { [4] Buygrid } \\
\text { framework } \\
\text { Robinson et al. } \\
\text { [47] }\end{array}$ & $\begin{array}{l}\text { Large system } \\
\text { models Sheth } \\
\text { [55], Webster } \\
\text { and Wind } \\
\text { [67] }\end{array}$ & $\begin{array}{l}\text { Operational and group choice } \\
\text { models Choffray and Lilien [12], } \\
\text { Corfman and Gupta [14], } \\
\text { Steckel [59], Rao and Steckel [44], } \\
\text { Wilson et al. [69] }\end{array}$ & $\begin{array}{l}\text { Large system model } \\
\text { expansion Johnston } \\
\text { et al. } \\
\text { [28] Spekman and } \\
\text { Gronhaug [57] }\end{array}$ & $\begin{array}{l}\text { Extension of buying } \\
\text { center-across firm } \\
\text { functions and } \\
\text { across the supply } \\
\text { chain Johnston and } \\
\text { Chandler, [27] }\end{array}$ \\
\hline $\begin{array}{l}\text { Timeline } \\
\text { (rough) }\end{array}$ & 1960s and earlier & $1970 \mathrm{~s}$ & $1980 \mathrm{~s}$ & $1990 \mathrm{~s}$ & 2000 and later \\
\hline
\end{tabular}

other stakeholders, whether within the buying organization or external to it (e.g., consultants, supplier firms, other firms in the industry). The group that makes the purchasing decision in turn is embedded in a network of individual and organizational relationships. Third, because of the high dollar volume, number of stakeholders involved, and often complex, technical nature of the offerings under consideration, the B2B purchasing process usually takes substantial time and may involve extensive bargaining and negotiations. The extended B2B purchasing process (which can take months or years) and its interactive nature (involving multiple members of both the buying and selling organizations) make it difficult to specify the functional relationships between the marketing efforts of a supplier and the responses by a buyer. Fourth, because B2B buyers are more interested in satisfying their total need than in buying any specific product, the offering can be complex and include training, technical support, financing, delivery terms, and so forth, such that neither the buyer nor the seller can easily determine which offer is best for the buyer.

In Table 1, we trace some major trends in B2B buying models, which reveal that many foundational models, developed three or four decades ago, are static and focused on a North American or European institutional structure. However, environmental forces emanating from technological advances and globalization are affecting the nature of B2B buying and challenging the validity of these models, along with their underlying assumptions.

Accordingly, Wiersema's [68] B2B agenda cites the need to focus on B2B buying as one of the three top domains of concern for B2B marketers. ${ }^{1}$ Through a Delphi-like process,

\footnotetext{
${ }^{1}$ The other two domains are B2B innovation and B2B customer analytics.
}

the Institute for the Study of Business Markets (ISBM; www. isbm.org) has identified four aspects that are of great concern to practitioners and offer the potential for fruitful academic study:

1. The changing landscape of $\mathrm{B} 2 \mathrm{~B}$ buying

2. Increasing seller sophistication

3. The impact of technological changes

4. Increasing importance and growth of emerging markets

The ISBM hosted a mini-conference in Orlando, Florida, in February 2014, to bring together leading B2B scholars who could exchange ideas in each of these domains and develop a research agenda for B2B buying. What follows are perspectives on each of these four important domains. We provide some background, identify key issues, and propose an associated research agenda for each case. We hope in turn that this article focuses attention on and leads to further research in these important domains.

\section{The Changing Landscape of B2B Buying ${ }^{2}$}

Centralization of buying at a global level has enhanced selling firms' focus on global key account management practices. Enhanced buyer knowledge, power, and discretion shift the balance of power away from sellers; the most important buyers (in terms of growth, volume, or otherwise) are often the most sophisticated and demanding, and the composition of the buying organization also seems to be changing, to include

\footnotetext{
${ }^{2}$ This section was primarily developed by Lisa K. Scheer and Robert F. Lusch.
} 
a broader representation and weight of non-procurement functions. Yet no clear picture has emerged regarding what is driving such changes or, in turn, how these changes might affect buying processes.

\subsection{BuyGrid Dimensions: Revisited and Adapted}

For nearly five decades, the BuyGrid model ([47]; see Fig. 1) has proven useful for understanding B2B buying, yet more recent macro-trends have significantly altered the B2B buying process [71], at an accelerating rate of change. First, political initiatives and regulations such as the U.N. Global Compact on Child Labor, U.S. legislative provisions regarding international accounting standards (i.e., the Dodd-Frank Act), and the EU's REACH (Registration, Evaluation, Authorization, and Restriction of Chemicals) and RoHS (Restriction of Hazardous Substances) standards for hazardous substances pose new, costly challenges that require buyers to carefully vet, document, and monitor global networks of suppliers, to an unprecedented degree. Second, the evolution of information and communication technologies has major implications for B2B buying [33]. Sharing information previously demanded costly, time-consuming efforts; now it can be transmitted at minimal costs and instantaneously, without geographic or temporal bounds. New technologies enable electronic marketplaces, data interchanges, and rich interactive collaborations among distant entities. Soon, physical objects embedded with digital processors will interface in the "Internet of Things" too (see http://store.elsevier.com/product.jsp?isbn= 9780124076846). These and other substantive business environment changes call for a revisitation and update to the BuyGrid.

The BuyGrid's sequential buying process indicates a comprehensive series of decision-making stages ("buyphases"). Modern B2B buying instead comprises four ongoing processes: implementation, evaluation, reassessment, and confirmation. Implementation encompasses all actions undertaken to acquire and receive goods and services directly, within the parameters of the current buying decision. Evaluation entails examining the conformance, effectiveness, and efficiency of all buying activities implemented within the parameters of the deal, such as rating seller performance or tracking acquisition cost metrics. Reassessment is scrutiny of the foundations on which current B2B buying decisions are based, including conclusions drawn from the evaluation of current buying activities; changes to the buyer's internal capabilities, needs, or priorities; and external factors, such as emerging opportunities and threats, offers from potential suppliers, or evolving market or regulatory demands. This strategic reassessment then leads to confirmation of the buyer's decision, whether as a renewal or minor modification of the existing buying decision or else the investigation, negotiation, and specification of a new one.
These processes are contemporaneous rather than sequential, with activities ongoing in each phase. Buying activities continue while other processes progress, and changes occur only when a new buying decision has been confirmed. Data are gathered and key metrics examined constantly to evaluate current buying activities. Sales proposals are examined, and buyer employees or hired consultants continually scan the environment for emerging opportunities. The degree to which buyer resources are invested in each process changes with the varying internal or external factors. For example, regulations force buyers to document their buying activities more fully, investigate suppliers more extensively, and reevaluate profitable current buying relationships using new criteria. Buyers' ability to compare prices instantaneously prompts them to seek ways to squeeze supply chain costs. Globalization also introduces proposals from new suppliers, generating more extensive strategic reassessments. When buyers and sellers gather extensive data, it alters their priorities and the nature of their negotiations. Developments in automation, the Internet, and information technologies also enable fully mechanized buying systems and face-to-face collaboration across vast distances.

In addition, BuyGrid's buying center concept highlights the importance of relevant buyer personnel. By building on this concept, we can glean insights from identifying the constellation of buying participants involved in each buying process, including buyer personnel, individuals and organizations external to the buyer (e.g., current and prospective suppliers, auditors, regulators), and inanimate entities and systems that perform activities formerly undertaken by people. The parties who confirm the buying decision and set the parameters for buying arrangements often differ from those who implement the buying activities. Analysts evaluate buying activities and pass their conclusions on to managers, who reassess the buying decision. Within negotiated parameters, buyer systems may communicate directly with supplier systems, implementing buying tasks without human involvement. The persons engaged in evaluation, reassessment, and decision making; the system design teams responsible for establishing mechanized buying systems; and the parties that implement the buying activities are geographically located according to various criteria and come together only as needed and often virtually, using telepresence technologies.

Despite the endurance of the BuyGrid classification of buying situations as new tasks, modified rebuys, and straight rebuys, the weaknesses of this model have long been noted (e.g., [70]). In an environment in which technologies create a global marketplace, it is more useful to consider the consistency versus degree of divergence in the buying elements that constitute the characteristics of the buy. These buying elements arise from four factors: (1) the goods and/or services acquired, (2) the terms of trade, (3) the selling firm, and (4) the buying firm. The buyer can seek to acquire the same products, similar products (e.g., new ancillary services, customized 


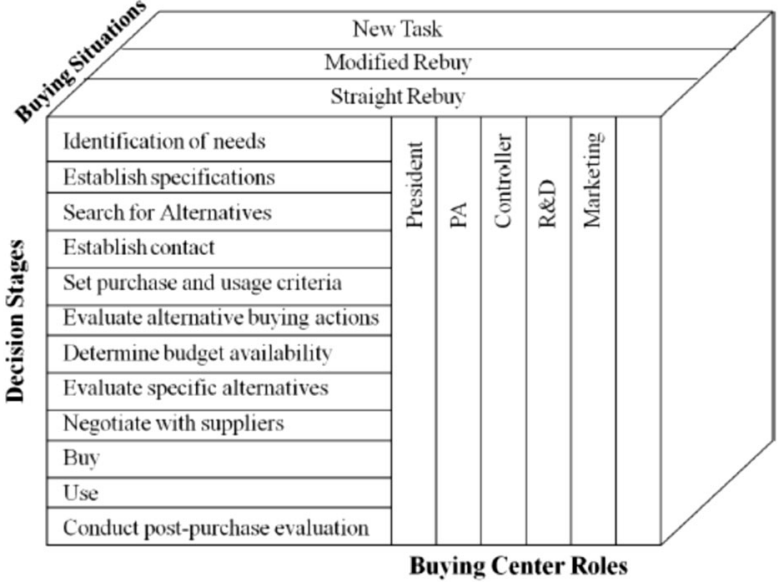

Source: Robinson, Patrick J. Charles W. Faris, and Yoram Wind, Industrial Buying and Creative Marketing, Boston: Allyn \& Bacon, 1967.

Fig. 1 The BuyGrid model

version of current product), or very different products (e.g., co-production, service solution vs. goods purchase) than previously bought. The terms of trade also might be identical, vary slightly in several aspects (e.g., price, delivery location, payment policy), vary greatly in one aspect, or differ on all terms. The buyer can deal with the same seller in exactly the same way, the same seller through a different interface (e.g., new salesperson, electronic system), a new business unit of the same seller, a new seller through the same interface (e.g., follow a salesperson to a new company, same electronic marketplace but a new seller), or a new seller through a new interface. The buying firm may change the personnel involved in the buying process, its buying interface, its corporate policies, and so on.

When considering the myriad buying elements, identical rebuys likely occur only through the implementation of previously negotiated and confirmed buying arrangements. On the flipside, seldom does a buyer experience a completely new buying situation, with no consistency in the buying elements. Thus, the most pertinent focus for our attention is analyzing (1) which buying elements are constant or in flux, (2) the degree of change in the inconstant elements, and (3) whether the changes are sought specifically by the buyer or seller, imposed by external parties, or occur naturally due to obsolescence or attrition.

Although it is helpful to reconsider the BuyGrid's dimensions as ongoing and possibly evolving buying processes, including both human and inanimate buying participants, other elements also merit attention: increasing globalization, government intervention in markets, value chain disruption, technological advances, and informed, empowered, demanding downstream buyers. All of these elements promote greater interdependence between buyer and seller firms [71], suggesting the need to consider the diverse interorganizational relationships through which B2B buying occurs.

\subsection{Modes of B2B Buying: Toward a New BuyGrid}

As buyer-seller interdependence increases, the nature of the buying relationships becomes more critical. In Table 2, we summarize three B2B buying modes that vary in the relationships between buyer and seller, the locus and nature of the buying decisions and their implementation, and other purchase-related factors.

\subsubsection{Routinized Exchange Relationships}

When acquired goods and services are consistent and predictable, routinized exchange relationships (RERs) are likely. In RERs, buying activities involve repetitive, routine interactions between authorized entities. The implementers enact standard ordering, receiving, and replenishment procedures within established parameters that have been devised by others, who confirm the buying decision and delineate the domain of authorized rebuying activities. Buying in RERs may be undertaken by individual boundary spanners representing the buyer and the seller, but increasingly, these routine activities are conducted by automated systems. In either case, RERs arise if the buyer and seller have a significant degree of interdependence; the establishment of the RER buying system further increases this interdependence, particularly when it includes systems integration.

Many decisions are necessary before implementing a networked electronic buying system though, including the specific goods and services to be acquired, the initial seller partner(s) involved, specifications for authorizing additional partners, procedures for adding new products, which algorithms can implement buying activities, the parameters within which automated buying operates, which factors trigger human intervention, and schedules for periodic human oversight. For ordering and some fulfillment activities (e.g., automated distribution centers), machines, systems, and algorithms perform the tasks, supported by a human technical staff that monitors ongoing processes, investigates exceptions, and exercises limited decision-making authority, within established parameters. At an extreme, RERs involve human representatives only in system creation, routine maintenance, and investigation of exceptions or performance outliers beyond established boundaries. As more physical goods gain "smart" capabilities, the viability of RERs should increase for a wider variety of purchasing contexts.

\subsubsection{Organic Buying Relationships}

Some B2B buying contexts are not amenable to routinization, so at the other end of the spectrum are organic buying relationships (OBRs), which require ongoing human involvement, interpersonal interactions, and adjustments between buyer and seller firms. Examples of OBRs include integrated 
Table 2 Modes of B2B buying

\begin{tabular}{|c|c|c|c|c|}
\hline & & $\begin{array}{l}\text { Routinized exchange } \\
\text { relationships (RERs) }\end{array}$ & $\begin{array}{l}\text { Transactional buying } \\
\text { operations (TBOs) }\end{array}$ & $\begin{array}{l}\text { Organic buying relationships } \\
\text { (OBRs) }\end{array}$ \\
\hline \multirow[t]{4}{*}{$\begin{array}{l}\text { Buying } \\
\text { processes }\end{array}$} & $\begin{array}{l}\text { Buying decision } \\
\text { confirmation }\end{array}$ & $\begin{array}{l}\text { Strategic partner selection } \\
\text { and setting parameters for } \\
\text { operations }\end{array}$ & $\begin{array}{l}\text { Tactical selection of vendor } \\
\text { and negotiating terms of } \\
\text { deal }\end{array}$ & $\begin{array}{l}\text { Strategic partner selection } \\
\text { and selection of initial } \\
\text { buyer representatives }\end{array}$ \\
\hline & $\begin{array}{l}\text { Buying activities } \\
\text { implementation }\end{array}$ & $\begin{array}{l}\text { Minimal or no variation in } \\
\text { buying elements }\end{array}$ & $\begin{array}{l}\text { Range from no to extensive } \\
\text { variation in buying } \\
\text { elements }\end{array}$ & $\begin{array}{l}\text { Extensive evolution in } \\
\text { buying elements and } \\
\text { buyer representatives as } \\
\text { needed }\end{array}$ \\
\hline & Buying activities evaluation & $\begin{array}{l}\text { Parties usually differ from } \\
\text { entity implementing } \\
\text { buying }\end{array}$ & $\begin{array}{l}\text { Evaluation occurs } \\
\text { periodically by different } \\
\text { party }\end{array}$ & $\begin{array}{l}\text { Ongoing evaluation by buyer } \\
\text { representatives and } \\
\text { oversight managers }\end{array}$ \\
\hline & $\begin{array}{l}\text { Buying decision } \\
\text { reassessment }\end{array}$ & $\begin{array}{l}\text { High relationship-specific } \\
\text { assets and } \\
\text { interdependence motivate } \\
\text { modifying than replacing } \\
\text { RER }\end{array}$ & $\begin{array}{l}\text { Determination if extant } \\
\text { conditions reveal } \\
\text { increasing criticality of } \\
\text { focal product or specific } \\
\text { supplier }\end{array}$ & $\begin{array}{l}\text { Despite high relationship- } \\
\text { specific assets, uncertainty } \\
\text { of goal achievement may } \\
\text { require pursuit of other } \\
\text { options }\end{array}$ \\
\hline \multirow[t]{2}{*}{$\begin{array}{l}\text { Locus of } \\
\text { participants }\end{array}$} & $\begin{array}{l}\text { Locus of purchasing } \\
\text { Decisions }\end{array}$ & $\begin{array}{l}\text { Centralized: complex } \\
\text { decisions regarding } \\
\text { resources to be acquired, } \\
\text { authorized sources, and } \\
\text { parameters of standard } \\
\text { buying procedures or } \\
\text { automated processes }\end{array}$ & $\begin{array}{l}\text { Centralized for high-volume } \\
\text { products, local for low- } \\
\text { volume products: spot } \\
\text { markets, auction } \\
\text { purchases, simple product } \\
\text { supply bids, ad hoc } \\
\text { buying activities, etc. }\end{array}$ & $\begin{array}{l}\text { Centralized for corporate- } \\
\text { level supply partnerships; } \\
\text { local for regional supply } \\
\text { relationships: solutions, } \\
\text { co-development, key } \\
\text { supplier-customer } \\
\text { partnerships, etc. }\end{array}$ \\
\hline & $\begin{array}{l}\text { Locus of purchasing activities } \\
\text { and implementation }\end{array}$ & $\begin{array}{l}\text { Centralized: enact buying } \\
\text { activities within } \\
\text { established parameters; } \\
\text { monitor ongoing } \\
\text { processes, investigate } \\
\text { exceptions. limited } \\
\text { number of supplier-buyer } \\
\text { interface points }\end{array}$ & $\begin{array}{l}\text { Centralized for high-volume } \\
\text { products; local for other } \\
\text { products: direct buying, } \\
\text { reception of acquired } \\
\text { resources for inventory or } \\
\text { use, and evaluation of } \\
\text { acquisition cost and } \\
\text { supplier }\end{array}$ & $\begin{array}{l}\text { Multiple supplier-buyer } \\
\text { boundary spanner } \\
\text { interface points: ongoing } \\
\text { activities to enact } \\
\text { solutions, fulfill contracts, } \\
\text { co-create value for } \\
\text { downstream customers, } \\
\text { etc. }\end{array}$ \\
\hline \multirow[t]{5}{*}{ Buy characteristics } & Complexity & High & Low to moderate & Moderate to High \\
\hline & Novelty & Low & Moderate & High \\
\hline & Importance & High & Low & Moderate to high \\
\hline & Uncertainty & Low & Low to moderate & Moderate to high \\
\hline & Time pressure & Moderate to high & Low & Low to moderate \\
\hline
\end{tabular}

solutions (e.g., paying for miles of use rather than buying tires), buyer-supplier product codevelopment, and key account relationships that enable the buyer to achieve customized goods, enhanced services, more consistent supply, or cost savings through operational integration. Negotiations with solutions providers likely remain centralized, because of the farreaching organizational changes required to pursue solutions rather than simply buy goods. Codevelopment projects with critical suppliers often are centralized; codevelopment with a niche supplier or that focuses on smaller-scale, marketspecific innovations may be located regionally though. To customize goods and services for empowered, demanding, evolving local markets, distributed buying that is located closer to these markets can lead to better detection of emerging trends and enhance capacities to secure authentic, reliable supply sources. Prior buyer-seller interdependence might exist, but the development and implementation of an OBR tends to increase both the buyer's and the seller's dependence on its counterpart [30].

For centralized buying decisions, advisory teams representing diverse functions reassess buying decisions, consider external and internal factors, and devise recommendations; final decision-making authority still typically resides with a single individual or small executive group. The implementation of confirmed buying decisions unfolds over time, requiring ongoing interpersonal contacts through numerous interfaces between buyer and seller (e.g., buying and sales agents, distribution, and traffic managers). Managers of boundary spanners evaluate the ongoing buying activities and adjust the implementation plan. When buying decisions are decentralized to local levels, individuals often participate in multiple buying processes. For example, 
the party who makes buying decisions may differ from those who implement buying activities, but the same manager likely evaluates current buying, reassesses the buying decision, and confirms the current relationship or selects a replacement supplier. In some cases, this manager, and other boundary spanners, also implements the buying activities.

\subsubsection{Transactional Buying Operations}

Finally, buying may occur through transactional buying operations (TBOs), defined as one-time agreements that impose neither obligation nor expectation on buyers and sellers to engage in future business. Examples include spot markets, auctions, bids for specified goods or services, and other ad hoc buyer-seller interactions. In contrast with the other modes, TBOs have a short time horizon: Decisions are confirmed; components and aspects of the deal are finalized quickly, and fulfillment is completed shortly thereafter. Demand is unpredictable, or products are relatively unimportant, so the tangible and intangible investments required to create and operate a RER would not be warranted. The goods and services are not complex, novel, or important enough to justify organizational and personal investments to create, cultivate, and nurture an OBR. Transactional buying tends to be centralized for high-volume buys but local for low-volume, low-cost buys. In TBOs, a single person may perform all buying processes, as long as performance metrics meet acceptable standards. Evaluation, reassessment, and confirmation by a supervisor likely occur only on a periodic schedule.

In such TBOs, buyer-seller interdependence is low, and investments in an RER or OBR cannot be justified by the importance of a product or the criticality of the partner. These TBOs also may occur in conditions of high interdependence asymmetry; the more dependent party may prefer an RER or OBR, but its less dependent counterpart has the power to insist on operating at a transactional level and thus can continually scan for alternatives. We anticipate that, over time, a smaller share of buying will be conducted through these TBOs. As Internet competition grows, buyers and sellers increasingly seek to form RERs and OBRs to achieve competitive advantages that they could not obtain through transactional buying. This shift bodes a more strategic role for B2B buying, because both RERs and OBRs are inherently longer-term decisions, involving non-recoverable, relationship-specific investments. Furthermore, both RERs and OBRs highlight the need to integrate the structure and organization of the buying decision strategically with its implementation. That is, a full accounting of buying must include the difficulties and costs associated with this implementation.

\subsection{Toward a Research Agenda}

Various research possibilities arise from the four dimensions of buying: implementation, evaluation, reassessment, and confirmation. In particular, we need descriptive research to describe and understand the current state of buying, as summarized in the following potential research questions:

- Are there circumstances in which the four buying processes are not contemporaneous? What subactivities and entities are involved in each process?

- Are they decentralized physically but integrated virtually?

- Will charting the cast of characters - animate and inanimate - involved in each buying process, across different contexts, reveal interesting differences or patterns?

- Can developing visual representations of the buying elements' consistency or variation reveal prototypical configurations in which specific sets of elements tend to covary?

- When and where do we find these modes of B2B buying?

- What market, macro-environmental, selling firm, and buying firm factors are associated with each mode?

- Are there other modes?

- Can research offer support for the implicit conjectures and theorizing presented in Table 2, or will it uncover other ways in which the modes are similar or differ?

Beyond descriptive assessments, B2B analytics research could model the performance implications of deploying different modes of buying and the associated types of relationships, of centralized versus decentralized buying decisions, and of centralized versus decentralized buying activities. Simulations might estimate the value-added contributions of different types of buying relationships, such as RERs or OBRs compared with TBOs.

In addition, empirical modeling or survey research should consider whether unexamined contextual factors alter the effectiveness or efficiency exhibited by different buying participants and in different modes of B2B buying. For example,

- What factors indicate that an automated RER will perform better than a human-implemented RER?

- In which conditions does local buying outperform centralized buying activities?

- What performance indicators should inform comparisons of the strengths and weaknesses of different buying modes?

As the strategic importance of buying and buying relationships increase, research attention to these and many other issues will offer significant potential to inform practice. Because B2B buying is an inviting area, in need of theory development and creative research, we hope this discussion prompts moves toward either a BuyGrid 2.0 or some other relevant framework. 


\section{Increasing Sophistication of Sellers: The Trend toward Solutions ${ }^{3}$}

With few exceptions, B2B suppliers confront increasing buyer power, as more buyers source on a global scale and actively seek to reduce their supply base [51]. As a result, for many suppliers, a small subset of large buyers accounts for a disproportionate share of sales, such that these buyers constitute critical strategic assets for the suppliers. Viewing buyers as strategic assets leads to the immediate consequence that suppliers must adopt a new mindset when dealing with key buyers. In addition to seeking a more collaborative relationship, suppliers increasingly are expected to cocreate value with and for buyers, such that they move beyond standard cost and quality improvements and seek to provide unique collaborative solutions. However, many traditional suppliers are not well positioned to address the solution- and cocreation-related challenges that require managing buyers as strategic assets [51]. Using Merton's [37] motivation-ability framework, we therefore attempt to identify and classify the trends that are moving sellers away from a product-centric view and toward a more collaborative, relational view of customer solutions.

\subsection{Motivation-Based Trends}

\subsubsection{Global Competition}

Competition on a worldwide level forces movements toward commoditization. For example, the commoditization of the personal computer (PC) industry was a major driver of IBM's decision to sell its PC business to Lenovo. Commoditization trends in general stem from two related factors: First, buyers seek to source products from the lowest cost suppliers, which frequently are located in emerging markets, to reduce their purchasing costs. Second, many suppliers have failed to differentiate their products, so buyers focus on price, which reduces the supplier margins.

\subsubsection{Fiscal Pressures}

These pressures on margins also require suppliers to manage their portfolios of buyers better. Successful suppliers tend to focus on profitable and avoid unprofitable buyers. With this focus on profitable buyers, suppliers work to help buyers improve their financial performance. That is, buyers seek suppliers not for their brand name or market share but for the supplier's ability to work closely with them to create winwin situations.

\footnotetext{
$\overline{3}$ This section was primarily developed by Sundar Bharadwaj and Robert Spekman.
}

\subsubsection{Survival of the Smartest}

Both these pressures, together with a trend among buyers to outsource their noncore activities, provide opportunities for suppliers that understand how to cocreate value with buyers, because they can differentiate themselves from competitors. Such "smartness" is evident in Dow Corning's decision to create the Xiameter brand to serve price-sensitive buyers, so that its flagship "Dow Corning" brand could target buyers seeking solutions that cocreated value.

\subsection{Ability-Based Trends}

\subsubsection{Increasing Network Thinking Capabilities}

Rather than an internal focus, sellers now pursue cocreation, such that both the buyer and seller are responsible for bringing new technologies to market. Such elaborate collaboration requires new skills (e.g., relationship building) of the seller. Because buyer-seller relationships involve multiple contacts between firms (e.g., sales reps and purchasing managers, sales managers and buyer financial officers, engineers in the two firms), network thinking becomes more prominent; in addition to interfirm buyer-seller networks, networks within both buyer and seller firms affect each specific relationship.

\subsubsection{Increasing Buyer Knowledge}

Advances in customer relationship management systems and other methods for obtaining deeper customer knowledge grant B2B firms greater ability to build collaborative relationships with key buyers. Such relationships go beyond the purchasing department, to include other functions and levels within the buying organization, and thus lead to increasingly sticky connections. Buyers seek knowledge-based value from their suppliers, who thus must drive interfirm relationship value.

\subsubsection{Improved Segmentation Skills}

As segmentation skills improve (e.g., need-based segmentation with Xiameter by Dow Corning), suppliers can better differentiate solution-seeking buyers from price-seeking ones. Suppliers must enhance their skills and ability to serve the segments they decide to target. For solution-seeking buyers, relationship-building skills are critical. For price-seeking buyers, an analytics-based approach is needed, and skills with managing big data are paramount.

\subsection{Research on B2B Solutions}

Three research streams have dominated prior literature on B2B solutions. First, some studies seek to distinguish between product-service bundles $[49,53]$ and true solutions that tend 
to distinguish products and services [62, 64]. These latter customer solutions typically involve outcome-based, contractual agreements that ensure specific performance achievements (e.g., number of miles instead of truck tires sold, tons of iron ore excavated instead of earth-moving equipment bought, flight hours instead of jet engines leased).

Second, environmental and firm-level factors might motivate the adoption of services. For example, Reinartz and Ulaga [45] note that firms suffering declining equipment sales increasingly focus on equipment installation and maintenance contracts, such that their revenues from service contracts can far exceed their previous equipment sales. Other studies similarly document performance improvements due to such service-focused strategies (e.g., [16, 17]).

Third, research has attempted to identify ability-related factors and the moderating conditions that determine their efficacy. For example, Tuli et al. [62] develop propositions about supplier processes and buyer characteristics that may relate to customer solution effectiveness. Using a theory-in-use methodology, Ulaga and Reinartz [64] identify the resources and capabilities necessary for the successful delivery of customer solutions. However, a shift to solutions does not automatically result in improved profitability or firm value [17]. Some suppliers of standalone products have transitioned successfully to customer solutions strategies, but many firms continue to struggle to offer profitable solutions [26, 58]. Two common internal roadblocks hinder the successful implementation of customer solution strategies: (1) the concern that such offerings expose firms to higher levels of risk and (2) fear of the loss of profits from their core goods $[68,72]$.

\subsection{Toward a Research Agenda}

Further research should provide a systematic validation and extension of the factors that prior research has identified as related to the increasing sophistication of sellers and solutions selling. Some key research questions include:

- What are the antecedents of a solutions strategy, along the dimensions of organizational structure, relational assets, and contracting ability?

- Which ability-related factors, strategies, and tactics are needed to develop the markets for customer solutions and ultimately sell to target segments effectively?

- As suppliers cooperate more to bring unique solutions to their buyers, who owns the buyer?

Beyond motivation and ability-related aspects, research on moderating conditions and outcomes should prove fertile. The B2B buying process for customer solutions often differs substantially from that for product selling. For example, the greater complexity and higher perceived risk associated with solution selling means that these decisions often take place at a higher organizational level and involve stakeholders of more diverse functional backgrounds, with potentially conflicting requirements. Therefore, fruitful research could investigate:

- How does the buying process differ between products and solutions?

- How does the selling process differ between products and solutions?

- How does the interaction between the buying team and selling team differ between products and solutions?

- What is the role of branding in solutions selling? Do firms use a single brand approach or adopt a cobranded/ ingredient branding approach?

Because buyers may choose to acquire a complete solution from a single supplier or pursue it from multiple suppliers, to leverage best-of-breed sets of components from each supplier, and suppliers similarly may provide the complete solution or collaborate with other suppliers to create a solution, some other research questions include the following:

- When should sellers collaborate in solution selling? What role should they play in the sale?

- In which circumstances (products, markets, levels of sophistication) are buyers better off constructing solutions from multiple sellers versus purchasing from a single supplier?

- What impact does partnering in solutions selling have on sellers' innovation?

Finally, insufficient empirical research explores the outcomes of a solution strategy, which provides an opportunity for research on metrics of solutions effectiveness and organizational adaptations to solutions. Some research questions include:

- What are the performance outcomes of solution selling at the offering, buyer, and selling firm levels?

- What organizational changes, at the buying firm and selling firm level, are needed to accommodate solutions selling?

- How do these changes and performance metrics shift over time?

\section{The Impact of Technology on B2B Buying Behavior ${ }^{4}$}

In this section, we focus on the impact of changing technology on B2B buying behavior. A classic view of decision stages from the industrial goods buying process (e.g., [47, 67]) broadly encompasses three phases: information gathering

\footnotetext{
${ }^{4}$ This section was primarily developed by Sundar Bharadwaj, Pranav Jindal, Murali Mantrala, Aric Rindfleisch, and Shrihari Sridhar.
} 
(for need identification, establishing specifications, searching for alternatives, and setting purchase and usage criteria), product evaluation/negotiation (setting budgets, evaluation of alternatives, negotiating with suppliers), and purchase/usage. This process reflects the concept of "creeping commitment," such that decision making involves a sequence of incremental choices, each of which eliminates some alternatives from further consideration [47]. But even 25 years ago, Wind and Thomas [70] speculated that the classic buying process would be affected by developments in information technology. At that time, Wind and Thomas [70] had more questions than answers and could hardly foresee the accelerated technological developments and diffusion brought about in the next two decades. In particular, we note two forms of emerging digital technologies with disruptive effects on the classic industrial buying phases: digital information technologies (DIT) and digital manufacturing technologies (DMT).

With DIT, we refer to the integration of telecommunications (e.g., smartphones, wireless technology), computer systems (e.g., software, audio-visual systems), and data that enable firms to access, store, transmit, and manipulate information pertinent to their daily business operations. Examples of DIT include Internet-enabled technologies such as social media, cloud computing, the Internet of things, smart mobility, and big data that help users access, curate, manipulate, and transmit information in real time, thereby improving firms' business process productivity. For DMT, we focus on the technologies themselves, such as digital design software, digital scanners, and 3D printers. These technologies enable firms to design, manufacture, and acquire objects independently, rather than buying them from an external supplier. Thus, auto manufacturers such as Ford use 3D printing to rapidly prototype light automotive components that can increase fuel economy and get them more quickly to market [13]. General Electric uses 3D printers to manufacture parts for its turbines [15].

Both DIT and DMT are enabled by the spread and power of the Internet, which has dramatically altered the nature of B2B buying by allowing firms to acquire rich, detailed product information from manufacturers, fellow buyers, or third-party reviewers. This information may include elements of a product's design, including its actual design files, which can be downloaded, printed, and even modified by buyers with access to DIT [3, 32]. According to Anderson [3], new technologies thus have the potential to usher in a new industrial revolution. Despite their potential role as game changers, the impact of DIT and DMT on B2B buying behavior has received relatively little scholarly attention - even as B2B marketing strategies, structures, and tactics are all likely to be radically altered by the emergence of these new technologies. To illustrate these probable effects, we discuss six B2B-related trends that DIT and DMT are likely to shape in the near future: (1) the growth of social buying and online communities, (2) desires for solution provider websites, (3) buyer-driven seller interventions, (4) desires for engaging sales interactions, (5) increased B2B buying center sizes, and (6) increasing uses of analytics.

To provide a conceptual framework for this discussion, we employ the classic BuyGrid model (Fig. 1). Although we have proposed a new BuyGrid framework (Table 2), to understand the changing landscape of B2B buying, the simpler, classic BuyGrid model is sufficient. Accordingly, in this section, we focus on the buying process (or buyphases) outlined at the outset of this section as a key reference point.

\subsection{Impact of Technological Trends on B2B Buying and Selling}

In Table 3, we detail how the six key trends associated with the emergence of DIT and DMT affect the three broad stages (information gathering, evaluation/negotiation, and purchase/ usage) of the buying process.

\subsubsection{Information Gathering}

The emergence of social buying has led to the formation of two segments of B2B buyers: traditional ones and social buyers, who rely extensively on social media and online communities (e.g., IT Knowledge Exchange) during the purchase process. Solution provider websites provide a primary source of information for buyers during the early stages of their buying process, and search engines have become a gateway to B2B content discovery. More than $70 \%$ of buyers begin their business purchases with research on Google [50].

With advances in DIT, the B2B buying and selling process also has become more buyer-driven than in the past. That is, B2B buyers invite B2B salespeople to engage at the buyers' discretion, and they might choose to engage with salespeople at any stage of the buying process. Advances in digital and information technologies also enable B2B buyers to use data analytics and streamline their purchasing, in tune with anticipated demand for their products. Buyers turn to online sources to research seller offerings and obtain product quality evaluations, which reduces their dependence on face-to-face events such as trade shows [35]. For the seller, recent industry surveys indicate that $60 \%$ of the buying process in a complex sale is complete before prospects even are willing to engage with a live salesperson (Marketing Leadership Council [36]). Moreover, increased information asymmetry favors B2B buyers; in one recent survey, $77 \%$ of B2B buyers indicated they would not talk to a sales rep until they had conducted their own independent research, facilitated by DIT (2012 Demand Gen Report). ${ }^{5}$

\footnotetext{
${ }_{5}^{5}$ http://www.demandgenreport.com/industry-topics/industry-news/ 1786-demand-gen-report-unveils-third-annual-b2b-buying-surveyshowing-preferences-built-prior-to-sales-engagement.html\#.VMHKGfwvIW assessed November 2014.
} 
The increased volume of product-related information available online also leads technology-enabled B2B buyers to expect more from sales reps. Thus, sales reps must move beyond content provision to offer potential buyers new perspectives on their market and creative solutions to their problems. Highquality sales interactions are especially important when buyers face high-stakes decisions; B2B sales organizations that provide insightful solutions (rather than product information) are more highly valued.

In response, some B2B selling firms are hiring cloud-based predictive analytics providers (e.g., Lattice, Mintigo) to collate internal data sources (e.g., marketing automation data) and external information (public data about companies' financial performance, company events, executive changes, social media activity, press releases, job postings, patents) to identify new leads. Firms also use these data to generate model-driven conversion rates, according to existing client "look-alike" traits. For example, new building lease signings or specific job postings might signal the expansion of potential customers into new markets, suggesting new opportunities for supplier firms. Other analytics enable sellers to monitor buyers' browsing behaviors on websites, which then help them understand the level of the buyer's readiness to purchase and transform cold sales calls to warm sales transactions, lowering their cost of sales.

The growth and diffusion of DMT is likely to have a transformative effect on how B2B buyers use this information too. Digital manufacturing technologies such as 3D printers allow firms to transform their ideas into objects [3]. Thus, information is the product. For example, UPS recently announced that it had installed 3D printers in hundreds of its retail stores, as part of its small business solution initiative. Using these printers, small firms can create (or download) digital files and print them for a variety of business-related uses, such as prototypes, replacement parts, or even small batch manufacturing.

\subsubsection{Evaluation/Negotiation}

The impact of DIT and DMT on the second step has been notable as well. First, advances in DIT allow more stakeholders to participate in buying decisions. According to a recent survey, the number of people involved in a large technology purchase increased from five in 2010 to seven in 2012 [18]. In response, sellers develop more multiperson teams to evaluate the heterogeneous information and resource requirements [35]. With the growth of analytic tools available to B2B buyers, marketing processes also are becoming more industrialized, which enables the provision of rapid, agile insights to buyers at the decision point.

Second, growing online communities provide buyers with a treasure trove of information, such as user reviews, that can help them evaluate lists of potential vendors. The responses by sellers include websites (e.g., Visa's Business Network, which targets small business customers) that enable customers to share ideas and respond to industry-specific queries. For Visa, the community features content but also generates useful leads [46]. Sellers such as Cisco and IBM leverage Twitter, Facebook, and YouTube to target social buyers and test and launch their new products.

Yet the rise of DMT also creates a new set of evaluation challenges, because B2B firms interested in leveraging the power of this new technology will gain options to rely on (internal) digital tools to design and craft their own components, rather than buying them from external suppliers.

\subsubsection{Purchase/Usage}

Online communities affect the B2B buying and selling process, as a form of both DIT and DMT. That is, these communities represent sources of valuable information, and they also provide access to digital designs that can be downloaded or modified for direct manufacturing. The digital design sharing site Thingiverse contains more than 500,000 designs, accessible for free, that users can manufacture with a desktop 3D printer. These designs provide a foundation for (potential) buyers to avoid the buying process entirely, or else enter into a distinct process in which they have their designs made to order by a 3D manufacturing house such as Shapeways, Ponoko, or Amazon.com.

Analytics also will play an important role in how DMT affects the purchase and usage stage of the buying process. The Internet of things can produce digitally manufactured products that feature rich sets of analytics, such as the time and place of manufacture, the identity of the machines used in their manufacturing, or their specific tolerances [32]. Moreover, the Internet of things enables increased connectivity among devices, creating new opportunities for firms to monitor and deliver services remotely and across the globe. Cisco offers building management services to large business clients from remote locations at significantly lower costs; DuPont promises smart crop monitoring using RFID devices included in seed packs.

Sellers also have begun to exploit DIT, such as in online forums, panels, blogs, webinars, and online demonstrations to share best practices and encourage cross-customer learning. Such actions enable them to enhance not only usage but also customer satisfaction, with significantly lower investments. A related implication is the increase in the ratio of inside-tooutside sales forces [35].

\subsection{Toward a Research Agenda}

In contrast with the substantial attention devoted to DIT and DMT in popular publications, such as The Economist, The New York Times, or Wired [2, 60, 65], scholarly research on 
Table 3 Impacts of changing trends on BuyGrid dimensions

\begin{tabular}{|c|c|c|c|}
\hline Trend & Buyphases & Buying center & Buying situation \\
\hline Growth of social buyers & $\begin{array}{l}\text { Buyers have more access to } \\
\text { information from multiple sources }\end{array}$ & $\begin{array}{l}\text { Data on competitive offerings } \\
\text { is available to buyers }\end{array}$ & Ambiguous \\
\hline $\begin{array}{l}\text { Solution provider } \\
\text { websites }\end{array}$ & $\begin{array}{l}\text { Buyers have more access to } \\
\text { information from multiple sources }\end{array}$ & $\begin{array}{l}\text { Data on competitive offerings } \\
\text { is available to buyers }\end{array}$ & $\begin{array}{l}\text { The purchase/usage process } \\
\text { becomes more efficient, } \\
\text { but it is not clear whether } \\
\text { buyers buy more or at } \\
\text { more profitable prices }\end{array}$ \\
\hline $\begin{array}{l}\text { Buyer-driven seller } \\
\text { interventions }\end{array}$ & $\begin{array}{l}\text { Buyers' information gathering needs are } \\
\text { more accessible, but buyers may not learn about } \\
\text { sellers' offerings in full, due to their selective } \\
\text { contact with sellers }\end{array}$ & $\begin{array}{l}\text { Transfer of power to buyer } \\
\text { side }\end{array}$ & Ambiguous \\
\hline $\begin{array}{l}\text { Desire for engaging sales } \\
\text { interactions }\end{array}$ & Ambiguous & $\begin{array}{l}\text { Buyers seek more } \\
\text { differentiated } \\
\text { seller information when } \\
\text { evaluating products }\end{array}$ & Ambiguous \\
\hline $\begin{array}{l}\text { Increase in B2B buying } \\
\text { center size }\end{array}$ & $\begin{array}{l}\text { Buyer need identification occurs in an } \\
\text { organization-wide fashion, with more diverse } \\
\text { needs identified through a large set of } \\
\text { stakeholders }\end{array}$ & Ambiguous & $\begin{array}{l}\text { Buying quantity increases, } \\
\text { while prices may drop }\end{array}$ \\
\hline
\end{tabular}

these technological trends is sparse [35]. Literature in digital and information technology domains largely focuses on macro-level studies of the development and functioning of B2B e-commerce (e.g., [52]), organizational participation [20], governance issues in B2B markets [19], or open product sourcing [34]. Little research investigates how DIT influences B2B buyer behavior within buying organizations or the related implications for B2B sellers and sales organizations. Likewise, we find little academic research that considers the business implications of DMT, though a notable exception is Berman's [7] overview of 3D printing technology and its potential marketing implications. This paucity of extant research leaves considerable opportunities for marketing scholars to investigate the effects of advances in both DIT and DMT on B2B buying behavior. In line with the structure of this section, we divide our recommendations into the three stages of the buying process:

\section{Information Gathering}

- Are B2B buying centers changing in size, composition, or complexity due to the influence of advancing DMT and DIT? Which buying center roles are increasing or decreasing in importance, and why? How do these changes vary by the type of product, purchase, or buyer-seller exchange relationship?

- Do technology-enabled interactions change the nature of marketing-sales relationships in B2B markets? Are marketing departments more important, as enablers of marketing communications content?
- How does DMT alter the nature and type of information acquired by B2B firms?

\section{Evaluation/Negotiation}

- What is the optimal B2B sales organization structure, in the face of technology-induced changes in B2B buying behavior?

- How will the ratio and role of inside-to-outside sales forces change due to DIT?

- What new competencies are required by B2B selling organizations? Does the sales force need more analytical skills? Are persuasive skills less relevant?

- What implications do technology-induced changes in B2B buying behavior have for the organization, staffing, training, deployment, and compensation of sales organizations?

Buying/Usage

- How are advances in DMT changing the nature of B2B buying? Which types of firms are using this emerging technology to make products rather than buying from a supplier?

- How are B2B buyer-seller interactions changing due to advances in technology? Are new technologies making interactions more transactional, consultative, or collaborative?

- Is the nature of products being sold changing, from goods to services? How does the buying and selling process for $\mathrm{B} 2 \mathrm{~B}$ services differ from that for $\mathrm{B} 2 \mathrm{~B}$ products? 


\section{The Growth of Emerging Markets ${ }^{6}$}

The growth of emerging markets such as China and India has dramatically reshaped the global marketplace, including primary demand, trade flows, and business practice. Although we know that accounting for the environmental context in which business transactions are embedded is critical to understanding B2B buying behavior, academic research and managerial best practices that largely reside in developed markets often get directly and inappropriately applied to emerging markets. Well-established literature on the standardization versus adaptation of marketing strategies suggests that $\mathrm{B} 2 \mathrm{~B}$ buying frameworks developed in what Henrich et al. [22] call the WEIRD nations (Western, Educated, Industrialized, Rich, and Democratic), when used with little adaptation or recognition of the economic, cultural, and regulatory differences between markets, lead to mixed results $[11,40,56]$. Thus, we need research to understand when extant B2B buying behavior frameworks can be extended to emerging markets and, even more important, when and how they should be adapted.

\subsection{Differentiating Emerging from Developed Markets}

Emerging markets are market economies that are large in terms of their population size, are rapidly growing, and have a low per capita income. The International Monetary Fund's [25] World Economic Outlook estimated, on the basis of the 2011 International Comparison program survey by the World Bank that emerging market economies account for about $56 \%$ of the share of the world's gross domestic product (GDP) at purchasing power parity. In contrast, in 1990, emerging markets accounted for only one-third of the world's GDP. Brazil, Russia, India, and China (the BRIC nations) are generally recognized as the largest emerging markets; they account for $40 \%$ of the world's population. In the past decade, their combined GDP (at purchasing power parity) grew at an annual rate of $6 \%-12 \%$, compared with a combined GDP growth rate for the $\mathrm{G}^{7}$ of $-3 \%$ to $3 \%$. These differences largely refer to consumer markets, but a critical distinguishing trait of emerging markets is that government spending as a percentage of GDP, on average, is lower than that in developed markets [61]. Yet, because other B2B buyers in emerging markets are smaller and fragmented, governments remain, on a relative scale, the largest non-consumer buyers, which have important implications for B2B sellers.

Size and growth rates are the most prominent differences between emerging and developed markets, but many other differences also might influence interfirm behavior. In Table 4, we identify some critical points of distinction (drawn from [9,

\footnotetext{
${ }^{6}$ This section was primarily written by Ujwal Kayande, Robert W. Palmatier, and Sundar Bharadwaj.

${ }^{7}$ Canada, France, Germany, Italy, Japan, the UK, and the United States
}

56]). Considering these significant differences between the two types of markets and the recognition that most growth in the global economy in the near future will come from derived demand from emerging market consumers, a key question that arises is how these differences influence extant models of B2B buying behavior.

\subsection{Emerging Versus Developed Market B2B Buying Behavior Research}

A 2012 McKinsey study, comparing the growth rates of firms headquartered in emerging and developed markets, showed that firms in emerging markets have a $13 \%$ growth rate advantage on average [5]. Only $3.4 \%$ of that advantage can be attributed to the smaller size of emerging market firms compared with developed market firms. Thus, there is something about the behaviors of emerging market firms that enables them to grow faster. The same study suggested three possible causes:

1. Higher reinvestment rate, such that emerging market firms reinvest more income into their businesses and pay lower dividends than developed market firms.

2. Agile asset reallocation, such that emerging market firms reallocate resources to higher growth rate areas more dynamically than do developed market firms.

3. Growth-oriented business models, such that emerging market firms tend to select lower cost, faster growing, larger markets, whereas developed market firms appear to select higher margin, smaller, more mature markets.

Various conceptual articles also explicate the differences between emerging and developed markets, as well as what those differences might imply for research in marketing and in other business disciplines (e.g., $[9,56])$. In one of the few articles dealing directly with B2B buying, Gu et al. [21] note the impact of network ties in China, and specifically the guanxi system, on firm performance. Being part of an informal guanxi network provides a market access advantage to members, though it also implies obligations that can hinder performance. The informal, noncontractual nature of the relationships in these emerging markets implies a different model of B2B buying behavior that depends more on personal networks, trust, and obligation than on formal, contractual agreements. Sheng et al. [54], studying business and political ties in China, also show that business ties have stronger effects than political ties on firm performance, but all the effects depend on the institutional and market environments. Economics research reinforces the notion that institutional differences are key drivers of economic growth variances across countries [1].

Prendergast et al. [42] examine B2B buying in the context of advertising agency-client relationships in China and 
Table 4 Key differences between emerging and developed markets

\begin{tabular}{|c|c|c|c|}
\hline & Specific characteristic & Emerging markets & Developed markets \\
\hline \multirow[t]{3}{*}{$\begin{array}{l}\text { Aggregate-level } \\
\text { market differences }\end{array}$} & Population & $\begin{array}{l}\text { Larger populations, estimated at } 40 \%-60 \% \text { of the } \\
\text { global population }\end{array}$ & $\begin{array}{l}\text { Smaller population, estimated at } \\
15 \% \text { of the global population }\end{array}$ \\
\hline & $\begin{array}{l}\text { Economic growth rate (GDP at } \\
\text { purchasing power parity) }\end{array}$ & Fast $(6 \%-12 \%$ per annum since 2000$)$ & $\begin{array}{l}\text { Slow or negative }(-3 \text { to } 3 \% \text { per } \\
\text { annum since } 2000)\end{array}$ \\
\hline & Heterogeneity of population & $\begin{array}{l}\text { Large income disparity, very heterogeneous in income, } \\
\text { education, individual buying behavior }\end{array}$ & Relatively homogenous population \\
\hline \multirow{4}{*}{$\begin{array}{l}\text { Individual consumer } \\
\text { differences }\end{array}$} & Price sensitivity & Relatively high & Relatively low \\
\hline & Brand importance & $\begin{array}{l}\text { Very high for higher income segments, but intense } \\
\text { unbranded competition at lower end }\end{array}$ & $\begin{array}{l}\text { Relatively less brand importance } \\
\text { disparity across consumers }\end{array}$ \\
\hline & Social norms & $\begin{array}{l}\text { Collectivist purchasing behavior, but wide variation } \\
\text { across population in level of influence }\end{array}$ & Individualistic purchasing behavior \\
\hline & Age & Relatively younger consumers & Aging population \\
\hline \multirow{3}{*}{$\begin{array}{l}\text { Institutional } \\
\text { environment } \\
\text { differences }\end{array}$} & Legal system & Evolving, opaque, slow legal system & Stable, transparent, fast legal system \\
\hline & Political environment & Volatile, not always democratic & Stable, democratic \\
\hline & Hard infrastructure & $\begin{array}{l}\text { Poor hard infrastructure (transport, roads, connectivity, } \\
\text { banking, etc.) }\end{array}$ & Well-developed hard infrastructure \\
\hline \multirow[t]{4}{*}{$\begin{array}{l}\text { Business context } \\
\text { differences }\end{array}$} & $\begin{array}{l}\text { Business to business } \\
\text { relationships }\end{array}$ & Large number of informal business relationships & $\begin{array}{l}\text { Relatively formal contractual } \\
\text { relationships }\end{array}$ \\
\hline & $\begin{array}{l}\text { Business to government } \\
\text { relationships }\end{array}$ & $\begin{array}{l}\text { Largest buyers are often government-owned } \\
\text { enterprises }\end{array}$ & Dispersed set of B2B buyers \\
\hline & Business and political ties & Strong influence of ties on ability to transact business & $\begin{array}{l}\text { Weaker influence of ties on ability to } \\
\text { transact business }\end{array}$ \\
\hline & $\begin{array}{l}\text { Labor, raw materials, and energy } \\
\text { costs }\end{array}$ & Relatively low & Relatively high \\
\hline
\end{tabular}

conclude that extant B2B buying models do a poor job explaining B2B buying in emerging markets. In a meta-analysis, based on countries representing $82 \%$ of global GDP, Samaha et al. [48] find that relationship marketing is more effective outside the United States than inside: The relationship effect on performance "is $17 \%, 15 \%, 38 \%$, and $55 \%$ more effective in Brazil, Russia, India, and China" than in the United States" (p. 21). This study and others like it demonstrate substantial differences in the efficacy of relationship marketing between emerging and developed markets. Ignoring these differences can lead firms to make poor marketing decisions. For example, in the retail industry, many successful retailers from developed markets have exited or significantly scaled back their operations in China, due to their failure to transplant their developed market channel strategy into emerging markets [40].

What is clear from this discussion is that the extant models built in developed markets do not necessarily describe B2B buying behavior in emerging markets. The important question to ask thus is, which differences between emerging and developed markets (Table 4) have the potential to fundamentally alter B2B buying behavior models, and which merely affect the scale of activities within extant models? Of the broad differences on four levels - aggregate market, individual consumer, institutional environment, and business context - the first two are perhaps more relevant to consumer markets, with at best indirect impacts on B2B buying through derived demand. The latter two differences instead could fundamentally change extant models of B2B buying, due to four elements: (1) the relative size and nature of government versus business buying, (2) underdeveloped legal systems, (3) the noncontractual, extensive webs of business relationships and their influence over the firm's ability to perform, and (4) the influence of business and political ties. The potential business risks created by these differences for developed market B2B firms are exacerbated by the relatively volatile political environments in many emerging markets.

\subsection{Toward a Research Agenda}

To develop an agenda for future research in this area, we classify B2B buying relationships into categories, according to where each partner in the relationship is located, as we show in Table 5.

In Cell 1, informal relationships dominate, because firms located in emerging markets buy from firms also located in the same or a different emerging market. Although some countryspecific research describes how business is conducted in emerging markets, as we cited previously, little research investigates how emerging market firms buy from firms located in other emerging markets. Considering the high volume of trade flows across emerging markets (e.g., China and 
Table 5 Research needs on organizational buying behavior within and across markets

\begin{tabular}{|c|c|c|}
\hline \multirow{2}{*}{$\begin{array}{l}\text { Selling } \\
\text { firms in }\end{array}$} & \multicolumn{2}{|l|}{ Buying firms in } \\
\hline & Emerging markets & Developed markets \\
\hline \multirow[t]{3}{*}{$\begin{array}{r}\text { Emerging } \\
\text { markets }\end{array}$} & $\begin{array}{c}\text { Informal-relationships } \\
\text { dominant }\end{array}$ & Brand-cost transition \\
\hline & Within a market & $\begin{array}{c}\text { How do/should emerging } \\
\text { market firms sell? }\end{array}$ \\
\hline & Across markets & $\begin{array}{c}\text { How do/should developed } \\
\text { market firms buy? }\end{array}$ \\
\hline \multirow[t]{2}{*}{$\begin{array}{r}\text { Developed } \\
\text { markets }\end{array}$} & Relationship transition & $\begin{array}{c}\text { Contractual-relationships } \\
\text { dominant }\end{array}$ \\
\hline & $\begin{array}{c}\text { How do/should developed } \\
\text { market firms sell? } \\
\text { How do/should emerging } \\
\text { market firms buy? }\end{array}$ & Extant research knowledge \\
\hline
\end{tabular}

Indonesia are among India's largest trading partners), this question underlies an important category for further research into $\mathrm{B} 2 \mathrm{~B}$ buying behavior:

- How do firms in emerging markets buy from other firms in emerging markets, including their own?

Cell 2 contains brand-cost transitions, or firms in emerging markets that sell in developed markets. Whereas emerging market firms traditionally built their businesses on cost advantages (e.g., labor cost arbitrage), as wages increase in these markets, such advantages are disappearing. In turn, the challenge for firms in emerging markets is to adopt higher margin strategies and deliver higher value product offerings. Some emerging market firms have successfully addressed this challenge, such as Embraer, Huawei, and Tata. Related research questions include:

- How can firms in emerging markets adapt to B2B buying practices in developed countries?

- What factors facilitate successful navigation up the value chain for selling firms in emerging markets?

- How can firms in developed markets change their B2B buying practices to take advantage of the lower costs offered by firms from emerging markets?

In Cell 3, contractual relationships dominate; this is the developed market context to which researchers have devoted the most attention. However, significant trends call for research even within this cell. For example, other sections in this review have identified the increased centralization of buying, sophistication of sellers, and advances in technology and analytics as major trends that already influence B2B buying behavior and demand further research attention.
Finally, Cell 4 involves relationship transitions, or firms in developed markets that sell to firms in emerging markets. It is likely to draw the most interest among both researchers and selling organizations in developed countries. Some key research questions are as follows:

- How should developed market sellers adapt their sales processes to address emerging market buyers in different geographies and industries?

- Can developed market firms learn to form relationships that drive business success in emerging markets? Are structures from developed markets, such as global account management, appropriate for emerging markets?

- Should firms partner with government-owned enterprises that are fiscally constrained? More generally, considering the notable role of governments in emerging markets, what is the best way to understand and address their role in different emerging markets?

- Should B2B firms in developed markets form public-private partnerships in emerging markets? If so, how?

- What are the drivers of demand in different emerging markets and various sectors within those markets?

\section{Conclusion}

Our goal with this article has been to provide new perspectives and an extended research agenda for each of the four main areas of B2B buying. Each of these areas offers great potential for academic research and invokes high practitioner interestexcellent recommendations indeed for research. But there is little low-hanging fruit here. The B2B buying cycles are lengthy; samples are small, and much of the research we have called for will need to be conducted in multiple, far-reaching geographies. However, the rewards for taking on these research challenges promise to be rich, and we hope many researchers respond to these calls.

\section{References}

1. Acemoglu D, Johnson S, Robinson JA (2005) Institutions as a fundamental cause of long-run growth. Handb Econ Growth 1:385-472

2. Anderson C (2010) Atoms are the new bits. Wired 18 (February): 58 $67 \& 105-106$

3. Anderson C (2012) Makers: the new industrial revolution. Crown, New York

4. Arrow KJ (1963) Social choice and individual values, 2nd edn. John Wiley, New York

5. Atsmon Y, Kloss M, Smit S (2012) Parsing the growth advantage of emerging market companies. McKinsey Q. https://www. mckinseyquarterly.com/PDFDownload.aspx?ar=2969 
6. Balakrishanan PV, Eliashberg J (1995) An analytic process model of two party negotiations. Manag Sci 41(2):226-242

7. Berman B (2012) 3-D printing: the new industrial revolution. Bus Horiz 55:155-162

8. Bonoma T, Johnston WJ (1978) The social psychology of industrial buying and selling. Ind Mark Manag 17:213-224

9. Burgess SM, Steenkamp JBEM (2006) Marketing Renaissance: how research in emerging markets advances marketing science and practice. Int J Res Mark 23:337-356

10. Cannon JP, Perreult WD Jr (1999) Buyer-seller relationships in business markets. J Mark Res 36(4):439-460

11. Cavusgil ST, Zou S (1994) Marketing strategy-performance relationship: an investigation of the empirical link in export market ventures. J Mark 58(1):1-21

12. Choffray J-M, Lilien GL (1980) Market planning for new industrial products. John Wiley, New York

13. Chowdhry A (2013) http://www.forbes.com/sites/amitchowdhry/ 2013/10/08/what-can-3d-printing-do-here-are-6-creative-examples/

14. Corfman K, Gupta S (1993) Mathematical models of group choice and negotiations. In: Eliashberg J, Lilien GL (eds) Handbooks in operations research and management science: marketing, vol 5. North-Holland, Amsterdam, pp 83-142

15. Council of Foreign Relations (2013) 3D printing: challenges and opportunities. http://www.cfr.org/technology-and-science/3dprinting-challenges-opportunities-international-relations/p31709

16. Dotzel T, Shankar V, Berry LL (2013) Service innovativeness and firm value. J Mark Res 50(2):259-276

17. Fang E, Palmatier R, Steenkamp JB (2008) Effect of service transition strategies on firm value. J Mark 72(5):1-14

18. Gerard, Michael, Zvaglesky I, Vancil R, Schaub K (2012) The 2012 IT Buyer Experience Survey: accelerating the new buyer's journey" vol 1, (October), IDC \#237207, Sales Advisory Service: Survey (http://www.idc.com/eagroup/download/accelerating-new-buyersjourney.pdf; assessed November 2014)

19. Grewal R, Chakravarty A, Saini A (2010) Governance mechanisms in business-to-business electronic markets. J Mark 74(4):45-62

20. Grewal R, Comer JM, Mehta R (2001) An investigation into the antecedents of organizational participation in business-to-business electronic markets. J Mark 65(3):17-33

21. Gu FF, Hung K, Tse DK (2008) When does Guanxi matter? Issues of capitalization and its dark sides. J Mark 72(4):12-28

22. Henrich J, Heine SJ, Norenzayan A (2010) Most people are not WEIRD. Nature 466(7302):29

23. Hutt MH, Reingen P (1987) Social network analysis: emergent versus prescribed patterns in organizational buying behavior, Proceedings, Association for Consumer Research, vol 14. Association for Consumer Research, Provo, pp 259-265

24. Iacobucci D, Ostrom A (1996) Commercial and interpersonal relationships; using the structure of interpersonal relationships to understand individual-to-individual, individual-to-firm, and firm-to-firm relationships. Int J Res Mark 13(1):53-72

25. International Monetary Fund (2014) An uneven global recovery continues, world economic outlook update, July 24

26. Johansson JE, Krishnamurthy C, Schlissberg HE (2003) Solving the solutions problem. McKinsey Q 2003(3):116-125

27. Johnston WJ, Chandler JD (2013) The organizational buying center: innovation, knowledge management and brand. In: Lilien GL, Grewal R (eds) Handbook of business-to-business marketing. Edward Elgar, Northhampton, pp 386-399

28. Johnston WJ, Chandler JD, Lewin JE (1996) Organizational buying behavior: toward an integrative framework. J Bus Res 35(1):1-15

29. Keeney R, Raiffa H (1976) Decisions with multiple objectives: preferences and value tradeoffs. Addison Wesley, Reading

30. Kumar N, Scheer LK, Steenkamp J-BEM (1995) The effects of perceived interdependence on dealer attitudes. J Mark Res 32(4):348 356
31. Lilien GL (2014) Organizational buying behavior. In: Winer RS, Neslin SA (eds) The history of marketing science. NOW Publishers, Hanover, pp 371-396

32. Lipson H, Kurman M (2013) Fabricated: the new world of 3D printing. John Wiley, Indianapolis

33. Lusch RF, Vargo SL, Tanniru M (2010) Service, value networks and learning. J Acad Mark Sci 38(1):19-31

34. Mallapragada G, Grewal R, Lilien G (2012) User-generated open source products: founder's social capital and time to product release. Mark Sci 31(3):474-492

35. Mantrala MK, Albers S (2012) Impact of the Internet on B2B sales force size and structure. In: Lilien GL, Grewal R (eds) Handbook of business-to-business marketing. Edward Elgar, Northhampton, pp $539-555$

36. Marketing Leadership Council (2012) The digital evolution in B2B marketing, The Corporate Executive Board Company www.mlc. executiveboard.com (assessed November 2014)

37. Merton RK (1957) Social theory and social structure. Free Press, Glencoe

38. Nash J (1950) The bargaining problem. Econometrica 18(2):155-162

39. Neslin SA, Greenhalgh L (1983) Nash's theory of cooperative games as a predictor of the outcomes of buyer-seller negotiations. J Mark Res 30(November):368-379

40. Palmatier RW, Stern LW, El-Ansary AI (2014) Marketing channel strategy, 8th edn. Pearson Prentice Hall, Upper Saddle River

41. Patton C, Balakrishnan PV (2012) Negotiating when outnumbered: agenda strategies for bargaining with buying teams. Int J Res Mark 29:280-291

42. Prendergast G, Shi Y, West D (2001) Organizational buying and advertising agency-client relationships in China. J Advert 30(2): $61-71$

43. Raiffa H (1982) The art and science of negotiation. Harvard University Press, Cambridge

44. Rao VH, Steckel JH (1991) A polarization model for describing group preferences. J Consum Res 18(1):108-118

45. Reinartz W, Ulaga W (2008) How to sell services more profitably. Harv Bus Rev 86(5):90-96

46. Renfrow J (2008) Small business owners get intimate with Visa's new network. Response 17 (December), 32

47. Robinson PJ, Faris CW, Wind Y (1967) Industrial buying and creative marketing. Allyn and Bacon, Boston

48. Samaha S, Beck J, Palmatier RW (2013) International relationship marketing. Mark Sci Inst Work Pap Ser :13-117

49. Sawhney M, Balasubramanian S, Krishnan VV (2004) Creating growth with services. MIT Sloan Manag Rev 45(2):34-43

50. Schwartz J, Kim D (2012) ITSMA how buyers consume information survey. (December) www.itsma.com (assessed November 2014)

51. Senn C, Thoma A, Yip GS (2013) Customer-centric leadership: how to manage strategic customers as assets in B2B markets. Calif Manag Rev 55(3):27-59

52. Shankar V (2012) B2B E-Commerce. In: Lilien GL, Grewal R (eds) Handbook of business-to-business marketing. Edward Elgar, Northhampton, pp 625-638

53. Shankar V, Berry LL, Dotzel T (2009) A practical guide to combining products+services. Harv Bus Rev 87(11):94-99

54. Sheng S, Zhou KZ, Li JJ (2011) The effects of business and political ties on firm performance: evidence from China. J Mark 75(1):1-15

55. Sheth JN (1973) A model of industrial buyer behavior. J Mark 37(4): $50-56$

56. Sheth JN (2011) Impact of emerging markets on marketing: rethinking existing perspectives and practices. J Mark 75(July):166-182

57. Spekman RE, Gronhaug K (1986) Conceptual and methodological issues in buying centre research. Eur J Mark 20(7):50-63

58. Stanley JE, Wojcik PJ (2005) Better B2B selling. McKinsey Q 2005(3): 15 
59. Steckel JH (1990) Committee decision making in organizations: an experimental test of the core. Decis Sci 21(Winter):204-215

60. The Economist (2011) Print me a Stradivarius: how a new manufacturing technology will change the world, February 10, 11

61. The World Factbook (2014) https://www.cia.gov/library/ publications/the-world-factbook/

62. Tuli K, Kohli AK, Bharadwaj SG (2007) Rethinking customer solutions: from product bundles to relational processes. J Mark 71(3):1-17

63. Turnbull P, Valla JP (1986) Strategic planning in industrial marketing: an inter-action approach. Eur J Mark 20(7):5-20

64. Ulaga W, Reinartz WJ (2011) Hybrid offerings: how manufacturing firms combine goods and services successfully. J Mark 75(6):5-23

65. Vance A (2011)The wow factor of 3-D printing. The New York Times, (January 12), B10

66. Van den Bulte C, Wuyts S (2007) Social networks and marketing. Cambridge, MA: Mark Sci Inst
67. Webster FE Jr, Wind Y (1972) A general model for understanding organizational buying behavior. J Mark 36(2): $12-19$

68. Wiersema F (2013) The B2B agenda: the current state of B2B marketing and a look ahead. Ind Mark Manag 42:470-488

69. Wilson E, Lilien GL, Wilson DT (1991) Developing and testing a contingency paradigm of group choice in organizational buying. $\mathrm{J}$ Mark Res 28(November):452-466

70. Wind Y, Thomas RJ (1998) The BuyGrid model: 30 years later, Wharton School. Work Pap

71. Wind Y, Thomas RJ (2010) Organizational buying in an interdependent world. J Global Acad Mark Sci 20(2):110-22

72. Worm S, Ulaga W, Bharadwaj S, Reinartz W (2014) Why and when should firms invest in customer solutions? An assessment of risk and return in business markets. Working Paper, HEC, Paris 